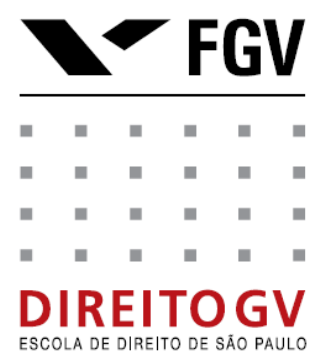

São Paulo Law School of Fundação Getulio Vargas - DIREITO GV

Research Paper Series - Legal Studies

Paper n. 89

\title{
Do Brazilian Courts Contribute to the Implementation of the Right to Housing?
}

\author{
Maria Laura de Souza Coutinho ${ }^{1}$ \\ São Paulo Law School of Fundação Getulio Vargas (DIREITO GV)
}

February 2014

This paper can be downloaded without charge from DIREITO GV Working Papers at:

http://direitogv.fgv.br/publicacoes/working-papers and at the Social Science Research Network (SSRN) electronic library at: http://www.ssrn.com/link/Direito-GV-LEG.html.

Please do not quote without author's permission.

\footnotetext{
${ }^{1}$ Researcher at DIREITO GV’s Justice and Constitution Center.
} 


\begin{abstract}
The objective of this paper is to try to understand the Brazilian's Courts role in the implementation of the Right to Housing. In order to do that, I analyzed three lawsuits (Favela Olga Benario, Favela Fiat/Vila Esperança and Pinheirinho I) in which the Right to Housing collide with the Right to Private Property. I claim that in spite of the adoption of the Social Function of the Ownership Principle and the formal inclusion of the Right to Housing among social rights protected by the Constitution, Brazilians Courts adopt a very conservative conception of the Right to Private Property and because of that, they tend not to enforce the Right to Housing.
\end{abstract}

Keywords: Judicial Activism; Social Rights; Right to Housing; Private Property.

\title{
Contents
}

1 Introduction 3

2 The Right to Housing in Brazilian Constitution and Legislation __ 4

2.1 The Right to Housing in the Constitution___ 4

2.2 The Principle of Social Function of Property __ 6

3 The Right to Housing in the Tribunal de Justiça de São Paulo___ 7

3.1 Favela Olga Benário Case___ 8

3.2 Favela Fiat Case __ 9

3.3 Pinheirinho Case _ 9

3.4 The Analyses of the Decisions ___ 11

4 Conclusion__ 12

References _— 13 


\section{Introduction}

This paper is a byproduct of a previous research in which I had systematized decisions in that the Right to Housing is mentioned and that were delivered by the Tribunal de Justiça de São Paulo from 2000 to 2012. I had concluded that in the small group of decisions in which there was a real conflict between the Right to Housing and the Right to Private Property, the Court tended to protect the Right to Property. However, I had also concluded that further investigation would be necessary in order to understand why this happens.

The objective of this paper is to answer this question by analyzing decisions in judicial disputes over land in which the Right to Housing collides with the Right to Property. I intend to show that Brazilian Courts adopt a very conservative approach to Property Right and therefore tend to enforce property rights disregarding evidences that demonstrate that the owner did not exercise his right in accordance with the social function of ownership.

Brazil's current Constitution was promulgated in 1988. It is characterized by a long Declaration of Rights, including many economic and social rights. However, although the Constitution alludes to the Social Function of Ownership, the Right to Housing was not formally included among Social Rights. It was only in 2000, after an amendment that this had happened. After the amendment, there was a rise in the numbers of actions involving the Right to Housing, but the alteration of the constitutional text had not, as it was expected, substantially modified the way Courts decide judicial disputes involving the Right to Housing.

The housing deficit is a serious and chronicle problem in Brazil. According to data collected in the Census that was held in 2010, 6\% of Brazilian population (about 11, 5 million people) lives in slums and tenements. According also to official reports from Ministério das Cidades, the federal office responsible for urban planning, Brazil must build more than 5 million homes to end the housing deficit. In this situation is natural that conflicts over land arise.

Land disputes usually initiate in possessory actions following the occupation of vacant lot by homeless families. In general, these lots are located in suburban areas and they are kept vacant while the owner waits to the price of land to rise. Sometimes the occupation is organized by social movements, but in most of the cases, it occurs gradually, after the invasion by a small group, when people call relatives and friends who also do not have where to live to build their homes in the neighborhood. The analyze of the decisions demonstrate that the Courts tend to 
enforce property rights even when there are strong evidences that the titled owner did not rationally use the land, as the principle of social function of property determines, or even have the actual possession of the area.

In conclusion, Brazilian Courts consider that the Right to Housing is an aspirational right and it is not immediately enforceable and that it does not actually impose limitations to the Right to Property.

The first part of the paper is theoretical. I will focus on the examination of constitutional and statutory provisions that govern the Right to Housing. In the second part, after a brief methodological introduction, I will analyze the selected judicial decisions. Finally, at the last part, I will present my conclusions.

\section{The Right to Housing in Brazilian Constitution and Legislation}

In this section, I will focus on the theoretical and historical aspects of the conflicts between the Right to Housing and the Right to Private Property and establish the questions I intend to answer with the analyze of judicial decisions that I will make in the section of the paper.

\subsection{The Right to Housing in the Constitution}

From 1964 to 1985, right wing military dictators had governed Brazil. They had suppressed opposition by torturing and killing their political adversaries. As soon as they gave up the power, discussions to approve a new Constitution began. New political forces emerged and collided and as a resulted twelve political parties participate at the discussions of the new Constitution. In a first moment, left wing politicians, from moderate socialists to radical communists united in the thematic sub-commissions and the first Constitution draft was socialist oriented.

While the discussions continued, the country was facing an economic crisis that defied all government measures. As a result, political moderates and conservatives, despite their party affiliation, joined in a coalition block to expedite the end of discussions and block the approval of 
the most polemic socialists' proposals. This conflict is quite evident in the final text of the Constitution as it is full of contradictions and unexplained omissions ${ }^{2}$.

In regards to the Right to Housing, this phenomenon appears in two different points of the text. First, there is the complete omission of the Right to Housing in the chapter dedicated to social rights and second, there is the inclusion of the Principle of social function of ownership in the Bill of Rights. To sum up, the Constitution did not contemplate one of the most basic social right and at the same time adopted a principle that poses polemic limits to the Right to Property.

Many authors claim that this omission is irrelevant because not only Brazil is signatory of international treatises, especially San Jose Pact ${ }^{3}$, that contemplates the Right to Housing, but also because the Right to Housing is, with no doubt, included in the concept of Human Dignity which was included in the Constitution, not as a "merely" Fundamental Right but as one of the bases of Brazilian federation.

Besides that, two different articles expressively mention the Right to Housing. The $7^{\text {th }}$ article which establishes what must be taken in consideration to calculate the minimum wage includes housing as one of the basic needs of people. Finally, the $23^{\text {rd }}$ article states that the Union, States and Municipal government have concurrent jurisdiction to create and implement housing programs.

In real life, however, the omission had huge impacts as the chart that demonstrates the number of lawsuits in Tribunal de Justiça de São Paulo ${ }^{4}$ shows. As soon as the amendment that included Right to Housing was promulgated there was a steady and significant increase in the number of lawsuits involving housing.

\footnotetext{
2 A complete narrative of the process of the 1988's Constitution text discussion, can be found in the article “Construção do Compromisso Maximizador: análise do processo constituinte e das características da Constituição de 1988” by Paulo André Nassar.

${ }^{3}$ San Jose Pact as part of the Inter-American treaty has the same effects of an ordinary law.

${ }^{4}<$ www.tj.sp.gov.br>. Last visited: March, 27, 2013.
} 


\begin{tabular}{|c|c|}
\hline Year & $\begin{array}{c}\text { Number of } \\
\text { demands }\end{array}$ \\
\hline $\begin{array}{c}1995 \text { to } \\
1998\end{array}$ & 0 \\
\hline 1999 & 6 \\
\hline 2000 & 14 \\
\hline 2001 & 27 \\
\hline 2002 & 45 \\
\hline 2003 & 51 \\
\hline 2004 & 70 \\
\hline 2005 & 273 \\
\hline 2006 & 313 \\
\hline 2007 & 287 \\
\hline 2008 & 311 \\
\hline 2009 & 356 \\
\hline 2010 & 363 \\
\hline 2011 & 529 \\
\hline 2012 & 530 \\
\hline
\end{tabular}

Despite the impressive elevation in the number of lawsuits, it is necessary to verify if the formal inclusion of the Right to Housing in the Bill of Rights had at any way modified the way Courts decide. Therefore, the first question I intend to answer with the analysis of the judicial decisions is if there was a change in the way Courts conciliate the Right to Housing and the Right to Private Property after the promulgation of the amendment that included the Right to Housing among the social right secured by the Constitution.

\section{2 The Principle of Social Function of Property}

It is not my objective here to discuss in deep the historical origins of the principle of social function of property. Actually, authors frequently disagree about that. Some of them claim that this principle is a development of Catholic principle of social function of the church, as exposed in Rerum Novarum Encyclical. Other authors affirm that the principle derives from Leon Deguit works. What I believe is important to mention is that the principle was first recognized in the German Constitution of 1919 that stated that property creates obligation. After the end of the 
Second World War, it was included in most of the new Constitutions of Latin American and European countries. In Brazil, it was included in the text of the 1934's Constitution and repeated in the texts of the Constitutions of 1937, 1946, 1967, 1969 and, finally, in the 1988`s Constitution.

The exact conception of Principle of the Social Function of Property, as of every other principle, depends mainly on judicial interpretation. Theoretically speaking, at least two opposed interpretation are possible. In a sense, the Principle of Social Function of Property only states that the Right to Property is not absolute and that it can suffer limitations in special cases. However, on the other hand, in a denser interpretation, it can mean that an owner cannot exercise his right of property without considering social needs and interests.

In my point of view, the text of 1988's Brazilian Constitution leaves no doubt that some uses of land are not allowed and, moreover, that an owner must have in mind that his property should be used in a way that it will not interfere with the well-being of other people. First, it determines that a high tax rate can be imposed to the owner of an urban lot that did not use or explore it. Most important of all, it states that in case of recidivism, it can lead to the expropriation of the area. Similar rules apply to rural areas. Because of that, I claim that the current Brazilian Constitution clearly states that the land must be used rationally aiming the welfare of the society as a whole. However, as I said above, at the end, it is up to the Judiciary to fix the conception of a principle that is used in given country. Therefore, it is crucial to verify how Courts decide.

In this context, the second question I intend to answer with the analyze of the judicial decisions is what is the usual interpretation Courts in Brazil give to the Principle of Social Function of Property and, consequently, what are the limitations it poses on the Right to Property.

\section{The Right to Housing in the Tribunal de Justiça de São Paulo}

As I said at the beginning, this paper is a byproduct of a previous research. In that research, I have classified decisions that mentions the Right to Housing delivered by the Tribunal de Justiça de São Paulo from 2000 to 2010 in four groups: 
(i) Lawsuits in which the Right to Housing collides with the Right of Public Property (occupation by homeless people of squares, schools or areas under bridges, for instance);

(ii) Lawsuits in which the Right to Housing collides with the Right to a Health Environment (occupation of reserves, banks of river and mangues ${ }^{5}$ );

(iii) Lawsuits in which the Right to Housing is used to question public policies;

(iv) Lawsuits in which the Right to Housing collides with the Right to Private Property.

I have concluded that the collision of the Right to Housing with the Right to Private Property emerges almost always in possessory actions after the invasion of private areas by homeless people. Because of that, I will focus on the analysis of this kind of action. I have chosen to analyze in detail only three recent cases: Vila Esperança, Favela Olga Benário, Pinheirinho I. I selected these cases for five reasons:

(i) The areas were private;

(ii) The areas had only one owner and this owner is known;

(iii) The occupation did not result of any planned action of social movements;

(iv) The areas were not environmentally protected;

(v) There families were not at risk, for instance, living in hillsides or bank of rivers.

Besides that, in all cases the order of eviction affected a great number of people, something between 1500 to 2000 people in each of them in a total of almost 8000 people.

In the sequence, I will briefly expose the facts surrounding the cases. The next and final step will be the analysis of the judicial decisions.

\subsection{Favela Olga Benário Case}

Olga Benário ${ }^{6}$ slum occupied a lot of 14.000 square meter in the south area of São Paulo city. According to social movements 700 to 800 families lived there, including children and elderly.

\footnotetext{
${ }^{5}$ Mangues area an ecosystem that exist in cost areas formed by detritus that come from the sea and rivers, inhabited by protected animals like crabs and some type of birds.
} 
The area belonged to a bus company that went bankrupt and owed more than 24 million Reais (about 12 million dollars) to federal government, not to mention tax properties to the Municipal government. Moreover, the owners of the company were formally accused of money laundering and of sending the money diverted from the taxes to tax havens.

The occupants produced strong evidences that demonstrated that prior to the occupation by the homeless families, the area was abandoned and was used by criminals to dump bodies and to sell drugs. Finally, there were already plans to expropriate the area aiming the construction of popular apartments as the south area of São Paulo concentrates the most of the housing deficit not only from São Paulo city but from São Paulo state as a whole.

Despite all this, the Courts ordered the eviction of the area. The order was fulfilled at the morning of $24^{\text {th }}$ August. Many occupants ended up literally in tents in the middle of the streets as there was not enough space in the shelters from São Paulo City Hall.

\subsection{Favela Fiat Case}

Favela Fiat was a neighborhood in Guarulhos, a dormitory city in the east area of São Paulo city. As almost all cities in São Paulo suburbs (Grande São Paulo), Guarulhos faces a very serious housing deficit and Vila Esperança is only one of areas illegally occupied by homeless families.

The occupation begun in 1992 when the area in one of the most important avenues of Guarulhos was abandoned following the bankruptcy of its owner, a Fiat retailer that used it as a parking lot. Due to the strategic location, the value of the area had increased. The 130 families that lived in the area tried to avoid the eviction in Courts claiming that they had acquired the area by adverse possession. The request was rejected by the local Judge and later also by the Court of Appeal.

Eventually, the municipal government expropriated the area after the federal government had committed to finance the construction of a popular condominium in the lot.

\footnotetext{
${ }^{6}$ Olga Benário was a German and Jewish communist militant. She was sent to Brazil to help José Carlos Prestes, the first Brazilian communist militant. They eventually fall in love and married. At the beginning of the Second World War, Olga Benário, who was pregnant at the time, was arrested and sent back to German by Getulio Vargas, who at the time was flirting with the Third Reich. Olga Benário died in a extermination camp in 1942. She is a martyr of the Communist Party in Brazil. It is interesting to note, however, that people who lived in the favela did not know who Olga Benário was.
} 


\subsection{Pinheirinho Case}

Pinheirinho was probably one of the most serious violations of Human Rights in Brazil in the last decades. Due to the violence during the fulfillment of the eviction order, Brazil was denounced to the Inter-American Court of Human Rights and is waiting trial.

Technically speaking, Pinheirinhos could not be considered a slum anymore. There were many brick houses and at least part of them was connected to mains electricity and water supply.

The area situated in São Jose dos Campos, an industrial city famous for being the headquarters of Embraer and Johnsons and Johnsons in Brazil, belonged to a company named Selecta that went bankrupt after its owner Naji Nahas, a Lebanese investor, were accused of breaking the Rio de Janeiro stock market in 1989 with fraudulent transactions. Later, in 2008, Nahas was arrested by the Federal Police after being accused of committing financial crimes and money laundering. Besides that, there are serious doubts about the regularity of the acquisition of the area by Naha`s group in early Nineties. According to some witness, the area where Pinheirinho was belonged to three brothers killed in 1968 during a robbery. They had never been married and did not leave any children. According to Brazilian law, in this situation, the heritage should go to the State government. It is not clear how during the Eighties the area ended up registered in the name of constructor who sold it to Selecta. Finally, Selecta owes 25 million Reais in $\operatorname{taxes}^{7}$ (about 12,5 million US dollars).

After the eviction order was pronounced, the families announced they would not leave the area peacefully. Shocking photos of men wearing motorcycling helmets and using car doors as shields hit the internet. The 5 thousand families organized barricades and surrounded the area with barbed wire. Considering the number of people to be removed and the probable confrontation, the local police asked for backup. The troops take about 48 hours to get to São Jose dos Campos. During this time, the Federal Government filled a lawsuit asking to the Federal Courts to sue an order to postpone the eviction until the federal and state government can offer an alternative to the families. However, according to Brazilian procedural laws, the Federal Courts

\footnotetext{
${ }^{7}$ According to the estimates, Select owns 11 million Reais to the Federal Government and 14 million Reais to Municipal Government.
} 
could not interfere in the performance of orders issued by State Courts. At the end, the order was fulfilled and until now, more than an year after, there are families who are still living in tents.

\subsection{The Analyses of the decisions}

The analyses of the selected decisions demonstrate that Courts use three main arguments to concede the eviction orders in possessory actions.

The first argument is that the Right to Housing does not create an obligation to the State to provide a house to every Brazilian family. According to the Courts interpretation, the only obligation of the State is to create a policy aiming the solution of the housing problem.

The São Paulo’s Court do not even question the efficiency or the reasonableness of this policy. As a matter of fact, judges affirm that any kind of intervention in the design of housing policies or implementation of housing is an undue interference in the discretion of the Administration. In the decision of Pinheirinho and Favela Olga Benário Case Courts affirmed that the Administration was aware of the situation and could have taken action to avoid the removal of the families. They conclude that if the Administration does not act, there is not anything Courts can do.

This corroborates that social rights, as José Reinaldo Lima Lopes argues, are seem by part of Brazilian Courts as nothing more than a form Christian charity and not as actual rights that creates obligations.

In my point of view, when Courts abdicate to this kind of review, the constitutionalization of social rights looses its point. As Charles Sabel claims in his text Destabilization Rigths: how public law litigation succeeds, Courts play an important role when they remove the Administration of its comfort zone. In this sense, judicial decisions can provoke changes, even when they not order directly what should the Administration do. Courts could order, for instance, the Administration to account for the enrollment of the removed families in housing programs.

It is also important to note that in cases involving the Right to Health, and also the Right to Education, the Courts do not respect the same kind of restraint. On the contrary, especially in cases involving the Right to Health, Courts usually order the provision of drugs or treatments despite Administration's allegations of lack of resources or of the disrespect of the Separation of Powers. 
The second main argument is that the State could not transfer to the regular citizen the burden of implementing a social right. In this context, establishing conditions to the removal of the families creates limits to the right of the owner that cannot be justified. This argument develops into the third argument as I intend to show below.

The last argument is that the Right to Property and the Right to Housing are both equally protected by the Constitution and when they collide, the Right to Private Property must be protected as the Right to Housing creates an obligation to the state and not to the regular citizen. I argue that the interpretation of the Right to Property that better fits the Constitution text must take into account the social function of ownership.

In the analyzed decisions, however, the limitations that the social function of ownership poses on the Right to Property were not even considered. For São Paulo’s Courts the allegation that the land speculation characterizes an abuse of the Right to Property when there are so many people without aces to land is not sound. Moreover, the fact that the owners did not pay the property taxes regularly did not change this conclusion. In the Pinheirinho's case, the judge declared to a TV station that the fact that there were tax debts was not relevant to the discussion in the possessory action. This kind of allegation is somewhat strange considering that according to Courts usual interpretation, the payment of taxes is an important evidence of the exercise of tenure.

\section{Conclusion}

The introduction of the Right to Housing in the Bill of Rights in 2000 have not changed the way Courts decide lawsuits in which the Right to Private Property collides with the Right to Housing. In comparison to the Right to Health and the Right do Education, the Right to Housing is the last enforced. In general, what the analyses of the decisions shows is that the Courts show deference to the Administrative decisions when the Right to Housing is at stake. Besides that, in the analyzed decisions not even the social function of property was taken into account when Courts interprets the limits of the exercise of the Right to Property.

I believe that the attitude of Courts towards the Right to Housing plays an important role in explaining why there were so little advances in the implementation of this right. 


\section{References}

ACCA, Thiago dos Santos. Uma análise da doutrina brasileira dos direitos sociais: saúde, educação e moradia entre os anos de 1964 a 2006. 2005. Dissertação (Mestrado em Direito), Faculdade de Direito, Universidade de São Paulo, São Paulo, 2005. p. 45-110.

ALFONSIN, Jacques Távora. A função social da cidade e da propriedade privada urbana como propriedade de funções. In: ALFONSIN, Betânia; FERNANDES, Edesio. Direito à moradia e segurança da posse no estatuto da cidade. Belo Horizonte: Fórum, 2004. p. 41-82.

CAVALCANTI, Clóvis. Escolhas autocráticas e vida de horrores: o caso da política habitacional. In: FALCÃO, Joaquim (Org.). Invasões urbanas: conflitos de direito de propriedade. Rio de Janeiro: Ed. FGV, 2008. p. 247-261.

DE SOTO, Hernando. The other path. New York: Basic Books, 1989.

DWORKIN, Ronald. O direito da liberdade: a leitura moral da constituição americana. São Paulo: Martins Fontes, 2006. p. 1-60.

Levando os direitos a sério. São Paulo: Martins Fontes, 2007. p. 35-46.

ELY, John Hart. Democracy and distrust. Cambridge: Harvard University Press, 1980. p. 1-16

FALCÃO, Joaquim. Justiça social e justiça legal: conflitos de propriedade no Recife. In: FALCÃO, Joaquim (Org.). Invasões urbanas: conflitos de direito de propriedade. Rio de Janeiro: Ed. FGV, 2008. p. 95-120.

FAUSTO, Boris. História concisa do Brasil. São Paulo: Edusp, 2008. p. 257-310.

FISS, Owen. Courts and social transformation in new democracies. Burlington: Ashgate, 2006. p. xi-xiv.

Um novo processo civil: estudos norte-americanos sobre jurisdição, constituição e sociedade. São Paulo: Revista dos Tribunais, 2004. p. 25-105.

FUNDAÇÃO JOÃO PINHEIRO. Centro de Estatísticas e Informações. Déficit habitacional no Brasil 2007. Belo Horizonte, 2009.

GARAPON, Antoine. O juiz e a democracia: o guardião de promessas. São Paulo: Revan, 1999.

GARGARELLA, Roberto. Theories of democracy, judiciary and social rights. In: GARGARELLA, Roberto; DOMINGO, Pilar; ROUX, Theunis (Orgs.). Courts and social transformation in new democracies. Burlington: Ashgate, 2006. p. 13-34. 
GARGARELLA, Roberto et al. Concluding reflections. In: GARGARELLA, Roberto; DOMINGO, Pilar; ROUX, Theunis (Orgs.). Courts and social transformation in new democracies. Burlington: Ashgate, 2006. p. 255-282

GLOPEN, Siri. Courts and social transformation: an analytical framework. In: GARGARELLA, Roberto; DOMINGO, Pilar; ROUX, Theunis (Orgs.). Courts and social transformation in new democracies. Burlington: Ashgate, 2006. p. 35-60.

HIRSCHL, Ran. Towards Juristocracy: The origins and consequences of the new constitucionalism. Cambridge: Harvard University Press, 2004.

HOLMES, Stephen. Passions and constraints. Chicago: The University of Chicago Press, 1995. cap. 5, p. 138.

LIEBENBERG, Sandra. The adjudication of social rights under South Africa's transformative constitution. [s.l.], [s.n.].

LOPES, José Reinaldo Lima. Direitos sociais - teoria e prática. São Paulo: Método, 2006. p. 57-88.

NASSAR, Paulo André. Construção do compromisso maximizador: análise do processo constituinte e das características da Constituição de 1988. In: DIMOULIS, Dimitri; VIEIRA, Oscar (Orgs.). Resiliência constitucional. São Paulo: DireitoGV, 2013. p. 25-34.

PIOVESAN, Flávia. Direitos sociais, econômicos e culturais e direitos civis e políticos. SUR Revista Internacional de Direitos Humanos, ano 1, $1^{\circ}$ semestre 2004.

PREZEWORSKI, Adam. The last instance: are institutions the primary cause of economic development. European Journal of Sociology, 45 (2), p. 168-188.

ROLNIK, Raquel. A cidade e a lei: legislação, política urbana e territórios na cidade de São Paulo. São Paulo: Studio Nobel; Fapesp, 2003. p. 101-144, 181-216.

SABEL, Charles F.; SIMON, William H. Desestabilization rights: how public Law litigation succeeds. Harvard Law Review, 1015, Feb. 2004.

SARLET, Ingo Wolfgang. A eficácia dos direitos fundamentais. Porto Alegre: Livraria do Advogado, 2005.

SAULE, Nelson Jr. O direito à moradia no Brasil: violações, práticas positivas e recomendações ao governo brasileiro - Relatório da Missão Conjunta da Relatoria Nacional e da ONU. São Paulo: Instituto Pólis, 2005.

SAULE, Nelson Jr.; RODRIGUEZ, Maria Elena. O direito à moradia. In: Extrema pobreza no Brasil: a situação do direito à alimentação e moradia adequada. Available at: <http://www.gajop.org.br/publica/expob_p.pdf>. Last visited: Sept. 28, 2010. 
SAULE, Nelson Jr.; RODRIGUEZ, Maria Elena. O direito à moradia como responsabilidade do Estado brasileiro. Cadernos de Pesquisa Cebrap, n. 7, maio 1997.

SEGAL, Jeffrey A.; SPAETH, Harold J. The Supreme Court and the attitudinal model revisited. Cambridge: Cambridge University Press, 2002. p. 1-43.

SEN, Amartya. Reforma jurídica e reforma judicial no processo de desenvolvimento. In: BARRAL, Weber (Org.). Direito e desenvolvimento: análise da ordem jurídica brasileira sob a ótica do desenvolvimento. São Paulo: Singular, 2005. p. 13-30

The concept of development. In: CHENERY, H.; SRINIVASAN, T. N. Handbook of development economics. Amsterdam: Elsevier, 1988. v. 1, p. 157-180

SHAPIRO, Martin. Courts: A comparative and political analyses. Chicago: The University of Chicago Press, 1981.

SWEET, Alec Stone. Governing with judges: Constitucional politics in Europe. Oxford: Oxford Press, 2000. p. 42.

SILVA, Afonso José. Curso de direito constitucional positivo. São Paulo: Malheiros, 2010. p. 104-105.

SOUZA, Sergio Iglesias Nunes de. Direito à moradia e de habitação: Análise comparativa e suas implicações teóricas e práticas com os direitos da personalidade. São Paulo: Revista dos Tribunais, 2008.

SUNSTEIN, Cass R. Social and economic rights? Lessons from South Africa. John M. Olin Law \& Economics Working Paper n. 124 (2 ${ }^{\text {nd }}$ Series $)$. Available at <http://papers.ssrn.com/paper.taf?abstract_id269657>. Last visited: Sept. 25, 2010.

TATE, Neal. Why the expansion of judicial power. In: TATE, Neal; VALLINDER, Torbjorn. The global expansion of judicial power. New York: New York University Press, 1995. p. 2738.

TAYLOR, Matthew M. O Judiciário e as políticas públicas no Brasil. DADOS - Revista de Ciências Sociais, Rio de Janeiro, v. 50, n. 2, p. 229-257, 2007.

VALLINDER, Torbjorn. When the courts go marching in. In: TATE, Neal; VALINDER, Torbjorn. The global expansion of judicial power. New York: New York University Press, 1995. p. 13-26.

VERÍSSIMO, Marcos Paulo. Ativismo judicial à brasileira. Revista de Direito GV, n. 8, p. 407440.

VIEIRA, Oscar Vilhena. A constituição e sua reserva de justiça. São Paulo: Malheiros, 1999. . Supremocracia. Revista de Direito GV, n. 8, p. 441-464, 2008. 
WALDRON, Jeremy. The core case against judicial review. The Yale Law Journal, 115:1346, p. 115, 2006.

WANG, Daniel Wei Liang. Escassez de recursos, custos dos direitos e reserva do possível na jurisprudência do STF. Revista de Direito GV, n. 8, p. 539-568.

YEPES, Rodrigo Primny. La judicializacion de la política em Colombia. [s.l.], [s.n.]. 